\title{
The Contribution of Migration to Sustainable Development: Western Vector of Migration from Central Asia (the US Case)
}

\author{
Mara Gubaidullina ${ }^{1}$, Zhasira Idrysheva $^{1 *}$, Gabit Zhumatay $^{2}$, Laura Issova $^{1}$, and Almagul \\ Kulbayeva $^{1}$ \\ ${ }^{1}$ Al-Farabi Kazakh National University, al-Farabi Ave. 71, 050040 Almaty, Republic of Kazakhstan \\ ${ }^{2}$ Columbia University, 525 West 120th Street, 10027 New York, USA
}

\begin{abstract}
The 2030 Agenda for Sustainable Development recognizes for the first time the favorable contribution of migration to sustainable development. This document is called the "declaration of interdependence", which is especially true for migration, which connects countries of origin and destination countries and has a huge impact on the lives of millions of migrants and their families. In the context of globalization, international migration has become a key challenge for both global development as well as for some state actors. At the present time there are several attractive centers on the planet for migration, which include highly advanced European Union countries, the United States, Canada and others. Although a number of issues of the migration process from the Central Asian republics to the United States are considered to be typical for any nation in the context of globalization, there are some regional peculiarities. The issue of immigration of the Central Asians to the United States is undoubtedly relatively a new and less studied phenomenon. The article provides a comparative analysis of the causes and consequences of the migration movement "overseas" in a country context, and its impact on diaspora relations. The goal of the article is to analyze of the migration process from the Central Asian republics to the United States in connection with international migration trends in the context of the Sustainable Development Goals (SDGs), and the Global Compact for Safe, Orderly and Regular Migration (GCM).
\end{abstract}

\section{Introduction}

In the light of globalization migration is one of the complex social processes that closely linked to economic, political and other changes in society. Therefore, the need for its regulation has long been recognized by experts, the public and governments around the world. The 2006 High-Level Dialogue on International Migration and Development (UN HLD) provided a powerful incentive to discuss these interlinked issues [1]. In the 2030 Agenda for Sustainable Development, eleven of the 17 Sustainable Development Goals

${ }^{*}$ Corresponding author: idrysheva7@gmail.com 
contain targets and indicators that are applicable to migration and mobility [2]. As a member of the Intergovernmental Conference on the adoption of the Global Compact for Safe, Orderly and Regulated Migration (GCM), held in December 2018 in Marrakesh (Morocco), Kazakhstan officially supported accession to this Global Compact on Migration.

The article analyzes the migration process from the Central Asian republics to the United States in a comparative context and based on statistical data. In the context of the analysis of different aspects of the issue motivations for migration and hardships that arise among labor migrants in the host country, as well as the problems and difficulties of the migration outcome for Central Asia are determined and assessed.

This article is written in the context of the proposals of the Special Working Group on the 2030 Agenda for Sustainable Development (December 1, 2018) that experts from academic and research institutes take part in in-depth case studies. A better understanding of the causes of migration will help to integrate migrants into other societies more effectively in practice, and contribute to the achievement of the SDGs, etc.

\section{Literature review}

The concept of Sustainable Development and theoretically sound UN initiatives are the initial methodological guide for a critical understanding of international migration and the study of the effects of migration in Central Asia as a single region. The 2030 Agenda, its goals and sub-goals/objectives determine the potential of international migration as a means of achieving a harmonious and balanced world. Initiatives developed at the summits of the Global Forum on Migration and Development (GFMD) are aimed at exploring the links between sustainable development and migration [3].

Classical concepts of the "Laws of Migration" by E.G. Ravenstein is often found in modern theoretical works by Massey D., Arango J., Hugo G., etc. [4]. The theory of mobile transition developed by W. Zelinsky has become the basis for many studies of the connection between migration and socio-economic development in the context of globalization [5]. In our work the spatial-temporal model of migration was chosen as the most suitable design, which reflects the role of globalization in the modifications and structural dynamics of international migration. The concept of mobile transition (Okolski, Olesen) is also a methodological basis for studying the relationship between migration and socio-economic development in the context of globalization [6]. It is also important to show the relationship between migration experience and the importance of place of residence and identity, as well as how this affects migration trends (Nayyar, Solimano) [7]. R. Skeldon identified the following five groups of regions ("regionalization of migration") that are involved to varying degrees in global migration flows: 1) the "old" and 2) the "world center" (core) with high rates of immigration (Europe, North America, Japan); 3) regions adjacent to the world center (expanding core): 4) the zone of labor emigration, where the labor frontier flows come from, including North Africa, and Southern Europe; 5) the so-called "resource niche" (Tropical Africa, Central Asia and Latin America), where migration flows are less clearly defined [8]. It is important that since the publication of R. Skeldon's classification, the states of postSoviet Central Asia have more clearly defined their role in international migration flows. They became the countries of origin of migrant workers and rose higher to zone 4 according to this classification.

An extensive database of documentary and statistical data on migration issues of a regulatory and political nature is held by international organizations, primarily the United Nations. Along with universal documents, international agreements are important, which together cover all aspects of international migration in the context of the SDGs, especially recently adopted [9-11]. The national laws of the Central Asian republics have implemented 
the fundamental provisions of the UN and the OSCE on migration issues.

Political and legal acts are important for a specific analysis of the conditions of migration and the situation of a migrant: Immigration and Citizenship Act 1990, REAL ID Act of 2005 $[12,13]$, which are rooted the US Constitution of 1787, the Fourteenth Amendment to the US Constitution of 1868, and laws on naturalization, citizenship, etc. An analysis of official statistics allows us to identify the dynamics of external migration by comparing the official data of the Central Asian countries with statistics from agencies of international organizations, primarily the UN: Portal of data on migration; the IOM (the International Organization for Migration) Global Migration Data Analysis Center, the World Bank etc. [14]. US migration agencies provide useful information about new migrants from Central Asia. Based on the summary data of several institutions, we compiled tables on the number of migrants in the United States arriving from Central Asian countries [15-17]. Along with the growing number of studies on international migration, there are very few authors studying migration in the regional dimension of Central Asia. Trends and problems of internal and external migration in the context of Kazakhstan, Central Asia and diasporas are an issue that in recent years has been increasingly on the local researchers often in collaboration with foreign scientists (e.g. Gubaidullina; Delovarova) [18, 19].

The authors of the book "Migration and Social Upheaval as the Face of Globalization in Central Asia" "take us as far as possible to the Uzbek migrants living in Istanbul, New York or Seoul", to migrants from Central Asia, "who returned to their "ethnic homeland". Foreign and Central Asian scholars seek to comprehend internal and external migration in a regional and global context: Central Asia and labor migration in the period global economic crisis (E. Sadovskaya, E. Marat, S. Massot); the return migration to Tajikistan (S. Olimova); Diaspora Policies and Repatriation Programs (O. Ferrando); et al., to which there is no single answer [20]. Two analytical reports on US labor migration from Kyrgyzstan (A. Chekirova) and Tajikistan (M. Buriev) are noteworthy [21, 22]. Migration is an important part of economy of Central Asian states and other post-soviet countries (Zh. Idrysheva, A. Kulbayeva) [23]. Issues such as labor migration from Central Asia to the United States as exemplified by migrants from Kyrgyzstan and Georgia are analyzed S. Libert [24]. The Central Asian migration flow as part of international migration, is the subject of attention to the problems of the post-Soviet space as a whole (C. Sadowski-Smith). The stereotype of thinking in the West defines migrants from Central Asia into the category of "immigrants from East Asia" as a hard-working and successful "model minority" [25], especially in research papers by F.T. Miko, G. Park, and S. Sulaimanova that raise the issue of illegal trafficking of women and children in the US from Central Asia [26]. Moreover, S. Pierce and A. Selee point to the problems of migrants in connection with changes in US immigration policy after Donald Trump's ascension to the presidency [27].

Since the early 1990s Central Asia has been the main supplier of migrants in the postSoviet space. Massive migrations according to Marlene Laruelle, due to social upheaval over the past twenty years affect management issues, models of social adaptation, individual and collective identities, and gender relations in Central Asia. We agree with the author that new trends in internal migration, as well as migration at the regional level, and beyond the borders of Central Asia, labor, educational and other migrations, and Kazakhstan calls "a new migration crossroads in Central Asia" [20].

\section{Methodology}

The scale and direction of migration are determined by the interaction of many variables: location of the country, place in the world economy; income distribution, unemployment; the education; the political regime, the life security; environmental (non)well-being, the presence 
of historical political and cultural ties, immigration policy, etc. [5]. Thus, the interdependence of the SDGs and the dynamics of external migration of Central Asia was revealed in the country and regional context using analytical, normative, comparative, and statistical methods.

In order to better assess the factors influencing the development of the migration process from Central Asia, and to gather empirical data, we used PEST and SWOT analysis of the overall picture of the migration process (general assessment of international relations and the external environment in relation to political, economic, social and other conditions in each of the Central Asian republics). In general, an integrated approach allows us to analyze and assess the implementation of potential migration resources, as well as take into account its positive and negative consequences.

\section{Results and Discussion}

\subsection{US Government Migration Policies and Migration Attractiveness of America}

One of the most important factors in the formation of American statehood and US prosperity was the influx of immigrants. Over the centuries the foundations of immigration regulation and US labor law have evolved. The existing share of immigrants in the total US population ( 329.45 million people) is about $14 \%$, that is, one in seven US residents in 2017 was a foreigner [28]. In the period from 1970 to 2015, their number quadrupled from less than 12 million to 46.6 million.

Towards the end of the $20^{\text {th }}$ century, more complex and voluminous immigration legislation had been formed in the USA, and in 1990 an updated law on immigration and citizenship was adopted initiated the program "ethnic diversity", which allows representatives of countries with low immigration to obtain permanent resident status in the United States [12]. In this case, what ethnic group do Central Asians in America belong to? The question remains open. A number of researchers consider this as a methodological problem. Nevertheless, in official documents of the USA and the UN we find different definitions. Central Asian ethnic groups are listed in the column "other ethnic groups." "Other ethnic groups" are sometimes considered Asians, sometimes viewed as part of another group, regardless of which country they are from. These include ethnic groups/nationalities such as Kazakhstanis or Kazakhs, Kyrgyzstanis or Kyrgyz, Tajikistanis or Tajiks, Turkmenistanis or Turkmens, and Uzbekistanis or Uzbeks [29].

Basically, immigrants make up a large army of the working population and are involved in various fields of economy. For example, in 2017 alone, 1.13 million immigrants received legal status of permanent residence in the country [30]. For all ethnic groups, the high demand for US immigration is primarily due to economic reasons.

Generally, there are three main factors that determine the importance of immigration from other countries to the United States such as highly qualified specialists who ease the burden on the US education system. This reduces the cost of training qualified personnel, the influx of labor with low qualifications and low wages.

The US policy on immigrants has undergone several changes that were formulated by the Trump administration in several regulatory documents to restrict the entry of new legal immigrants, specifically presidential decree "Protecting the country from foreign terrorists trying to enter the United States of January 27, 2017, "Kate's Law," "Prohibition of Asylum for Criminals Act". The annual quotas for issuing Green cards were halved from 110,000 people per year up to 55,000. Trump justified the adoption of such measures by the need to 
curb terrorism [31]. In 2017, every second application for a tourist visa from Central Asia was denied. Traditionally, the determination of the goals and main directions of immigration policy, as well as the adoption of relevant legislative acts are within the competence of the US Congress. Mostly, the institutional, political and legal system of the United States, social security and political freedoms are in favor of this country's sustainable attractiveness for migrants.

\subsection{The migration process from the Central Asian region: country profile}

As of 2018, Russia, Germany and the United States became the top three destination countries where migrants from Central Asia migrate. In this sense, the Asian diaspora of the United States is 12.8 million people, and Central Asian immigrants are a tiny part of this community [32]. It needs to be noted that the Central Asian diaspora is a growing community not only in Europe but also in North America, with many interconnected identities such as Asian, post-Soviet and Muslim, urban and rural.

The features of the migration problem for the countries of the post-Soviet space is that since the beginning of the 1990s all the main migration flows have been mainly forced in order to find employment, more efficient application of their professional skills, and better social conditions. Although political motivation for leaving their home countries had been initially provided only in individual cases, after the 2000s this reason became more common among immigrants from all countries of Central Asia. As a result, not only Tajiks, Uzbeks or Turkmens, but now also Kyrgyz and Kazakh immigrants are frequently referring to political motivations when they leave their homeland.

The mechanism of legal migration in the USA is typical for most countries. This is part of the Green Card Lottery, which gives immigrants the legal right to live, work and study in the United States. Based on the results of the annual win of the Green Card DV-2020 lottery, which is carried out in accordance with section 203 (c) of the US Immigration and Citizenship Law, the Kentucky Consular Center, Williamsburg posted the following data for each Central Asian country: Uzbekistan - 1743, Kazakhstan - 1584, Tajikistan - 1401, Kyrgyzstan - 1223 and Turkmenistan - 515. Thus, out of 55,000 Green Card visas 6466 or $11 \%$ are in Central Asia. It is worth noting that according to a statistical breakdown, five Central Asian countries are registered in the "Europe" section [33].

Interestingly, most of all citizens of Uzbekistan get the opportunity to travel to the USA by Green Card. It is estimated that between 1991 and 2018 there were 95.310 thousand people from Uzbekistan that due to Green Card could travel and settle in the US [17], that is, approximately 3,530 people per year. In addition to this, after 2010 the average rates of newcomers from Uzbekistan significantly increased, more than 4 thousand people per year. Such dynamics has been typical for subsequent years. Within five years from 2014 to 2018 22,237 people left Uzbekistan [15,16], that is, an average of 4,517 people per year (Table No2). Over the same five-year period, 6,487 migrants left Kazakhstan, that is, an average of approximately 1297 people per year (Table No1). With respect to Kyrgyzstan, 3,967 citizens immigrated from this country during this period, that is, approximately 794 people per year (Table No3). Regarding Tajikistan 3.249 citizens immigrated from the country, or 650 people per year (Table No4). Finally, 1,252 Turkmen citizens immigrated to the US, that is, approximately 251 people per year (Table No5).

In the field of labor migration there is a general tendency, which manifests itself in two ways on the one hand, the use of any conditions for permanent migration on a legal basis in order to obtain citizenship, and on the other hand, there is a stable reason for temporary (mainly illegal) labor migration from different social and educational backgrounds of the population. As can be seen, accordingly, two categories of labor migrants participate in the 
migration process. One category of migrants is people with high professional status, usually with higher education and labor skills. As a rule, they are in demand in the US labor market because they have good command of English, are able to legally obtain work visas and US citizenship. The second category of migrants is people with low qualifications and skills. Although they legally entre the USA, they illegally get a job, as a rule, having tourist and other types of visas. In general, it needs to be noted that most migrants from Central Asia for the most part have higher education, and respectively higher quality skills in comparison with the level of education of migrant workers from Central or South America.

As a rule, the US immigration policy is pretty tough on illegal immigrants from Central Asia. Despite the relatively low percentage of illegal entry and stay in the United States, the number of visa denials from American consuls is high. Significant difficulties with obtaining visas arise in connection with the immigration policy of Donald Trump. Despite the relatively low percentage of people from Central Asia illegally staying in the USA, the percentage of visa denials from US consulates is quite high. Particularly, stringent measures are being taken by the US Migration Service for citizens of Turkmenistan. In 2019, strict migration rules were introduced for citizens of Kyrgyzstan.

The migration process from the Central Asian countries to the United States has some common features depending on a particular country.

\subsection{Migration from Kazakhstan}

As of 2019, the total population of Kazakhstan was 18.9 million people, and the migration growth of the populations from different countries was plus 34,983 people [29]. According to the interim census for five years (2007-2011) in the United States, there were 24.636 US residents from Kazakhstan [33].

Kazakh immigration to the United States dates back to around the mid 1960s. By that time, there were about 20 Kazakh families in America. The growth of the Kazakh diaspora in the United States was mainly due to mono-ethnic and inter-ethnic marriages, especially since 1991 thanks to the Diversity Immigrant Visa program. Currently, Kazakh Americans are one of the peoples inhabiting North America and being citizens either of the United States and Canada. According to G. Mendikulova, several groups of Kazakhs are based in the United States. Among them are Kazakhs from Turkey, who were an integral part of Turkish labor immigration; Kazakhs who emigrated from China to the United States through Japan or Taiwan; Kazakhs who emigrated from the Soviet Union; Kazakhs from Kazakhstan who arrived to study or in search of work in the 1990s, etc. [34].

Unlike the older generation, young people are trying to find a life partner from the Kazakh environment with the intention of preserving their ethnic identity.

Table 1. Migration from Kazakhstan to the USA. The number of persons obtained the status of U.S.

\begin{tabular}{r|r|r|r|r|r|r|r}
\hline Year & $1991-2001$ & $2002-2010$ & $2011-2015$ & 2016 & 2017 & \multicolumn{1}{|c}{2018} & \multicolumn{1}{c}{ Total } \\
\hline legal resident & 9925 & 16,335 & 6100 & 1310 & 1377 & 1378 & 36,425 \\
\hline refugee & 987 & 1062 & 153 & 91 & 39 & 47 & 2379 \\
\hline citizenship & 1287 & 6500 & 4448 & 760 & 729 & 823 & 14,547 \\
\hline Total & 12,199 & 23,897 & 10,701 & 2161 & 2145 & 2248 & 53,351 \\
\hline
\end{tabular}

Data based on summary data [15-17] (Calculated by us - M.G. \& Z.I.)

The geography of the settlement of Kazakh communities in the United States is not very wide. Kazakhs live mainly in Reston, in the western part of Fairfax County in northeastern Virginia. Citizens of Kazakhstan traveling to the United States receive more and lower visa 
costs than citizens of other Central Asian countries (business, educational, medical, immigration).

\subsection{Migration from Uzbekistan}

Compared to other Central Asian countries, Uzbekistan is the most densely populated republic of the region. As a result, the volume and dynamics of the migration movement from Uzbekistan exceeds other countries in the region. Fairly high migration rates persist over a long period. Considering that the population of Uzbekistan today is about 32.3 million people, and the migration growth is minus $(-42,521$ people a year or an average of minus 118 people a day), the population decline due to external migration is very high (minus 42 521 people) [29].

Uzbeks were previously involved in the migration flow before other ethnic groups in Central Asia. A significant part of the Uzbeks lives mainly in New York and in the north of New Jersey, San Antonio, Houston, Philadelphia and other areas of the US.

The demographic picture of immigrants from Uzbekistan is the most dynamic among Central Asian communities in the US (see Table 2).

Table 2. Migration from Uzbekistan to the USA. The number of persons obtained the status of U.S.

\begin{tabular}{c|c|c|c|c|c|c|c}
\hline Year & $1991-2001$ & $2002-2010$ & $2011-2015$ & 2016 & 2017 & 2018 & Total \\
\hline legal resident & 24,973 & 33,936 & 23,335 & 4359 & 4095 & 4612 & 95,310 \\
\hline refugee & 2192 & 2445 & 399 & 41 & 35 & 27 & 5,139 \\
\hline citizenship & 7458 & 14,164 & 11,401 & 1685 & 1498 & 1532 & 37,738 \\
\hline Total & 34,623 & 50,545 & 35,135 & 6085 & 5628 & 6171 & 138,187 \\
\hline
\end{tabular}

Immigrants from Uzbekistan more often receive American citizenship mostly legally. According to experts from the State Department's migration service and law enforcement agencies, the Uzbek diaspora is a mobile, vibrant, and organized ethnic group. Representatives of the Uzbek diaspora are law-abiding and rarely violate the law. A distinctive feature of the Uzbek diaspora in the United States is its cohesion and commitment to the traditions and culture of the ethnic group.

\subsection{Migration from Kyrgyzstan}

Currently, the population of Kyrgyzstan is 6.4 million people and the migration growth of the population has a negative balance of an average of minus -70 people per day, in general, for a number of reasons, emigration prevails over immigration [29]. According to Chekirova, from 1999 to 2017, more than ten thousand Kyrgyz migrants received legal US citizenship in various ways: green cards (DV), family reunion, labor migration, refugees [21]. During the same period, about 50,000 Kyrgyz citizens had a non-immigration status, which meant only a temporary stay in the country: temporary stay, business visits, tourism. After 2010, the number of legal migrants with non-immigrant status has been increasing. A large group includes students and participants in the educational programs of the US Department of State: FLEX, Muskie, Fulbright, Humphrey, etc. Their number decreases after 2011. According to our estimates, over five years (2011-2015) 1978 citizenship received US citizenship, and in general, including 2018 - 5572 people (see Table 3).

The first wave of Kyrgyz migrants in the 90s was mainly engaged in "black" physically difficult work, as well as all the others from the former Soviet Union: cleaners, taxi drivers, builders, caring for the sick, elderly people, nannies, etc. The so-called "marriage migration", fictitious marriages with US citizens are common among Kyrgyz migrants in the US. Today, 
migrants from post-Soviet republics arrive in Western countries with a higher professional level, or seek to find work that is more qualified in their specialty - in industry, financial institutions, business, in the service sector, etc. Educational migration is currently one of the priority goals among the studying youth of Kyrgyzstan. However, the conditions for granting US visas to Kyrgyz citizens have been tightened. Until 2012, young people could enter the United States under the Work \& Travel student exchange program, and apply for an F1 (J1) visa on their own, staying in the country until the Green Card was officially received.

Table 3. Migration from Kyrgyzstan to the USA. The number of persons obtained the status of U.S.

\begin{tabular}{c|c|c|c|c|c|c}
\hline Year & $2002-2010$ & $2011-2015$ & 2016 & 2017 & 2018 & Total \\
\hline legal resident & 5019 & 3339 & 847 & 715 & 908 & 10828 \\
\hline refugee & 383 & 123 & 40 & 25 & 12 & 583 \\
\hline citizenship & 2291 & 1978 & 408 & 412 & 483 & 5572 \\
\hline Total & 7693 & 5440 & 1295 & 1152 & 1403 & 16983 \\
\hline
\end{tabular}

Data based on summary data [15-17] (Calculated by us - M.G. \& Z.I.)

In 2019, the Trump administration imposed restrictions on the issuance of immigrant visas and green cards (DV) to citizens of Kyrgyzstan and several other countries "due to the lack of security measures in identity documents" [35]. The Kyrgyz diaspora in the United States, unlike the Kazakh or Uzbek, is small and relatively new, it is in its formation [21].

\subsection{Migration from Tajikistan}

The total population of Tajikistan is more than 9.4 million people. In 2014 the number of Tajiks in the United States was slightly more than 2,000. Waves of migrants from Tajikistan to the United States throughout the entire period remain at the same level. Approximately a little more than 500 people travel to the United States annually. Accordingly, over the past five years their number has been 2,760 .

Table 4. Migration from Tajikistan to the USA. The number of persons obtained the status of U.S.

\begin{tabular}{c|c|c|c|c|c|c}
\hline Year & $2002-2010$ & $2011-2015$ & 2016 & 2017 & 2018 & Total \\
\hline legal resident & 1898 & 2454 & 593 & 652 & 893 & 6490 \\
\hline refugee & no data & & & & & \\
\hline citizenship & 1352 & 766 & 212 & 222 & 261 & 2813 \\
\hline Total & 3250 & 3220 & 805 & 874 & 1154 & 9303 \\
\hline
\end{tabular}

Data based on summary data [15-17] (Calculated by us - M.G. \& Z.I.)

The largest Tajik communities in America are located in New York, California, Nebraska and the District of Columbia. Residents of Tajikistan with great difficulty are granted a visa to enter the United States, but generally they receive green cards through requesting political asylum. Across the US there are several Tajik associations operate such as the AmericanTajik Association in Brooklyn, New York, as well as the Tajik-American Cultural Association (TACA) in Fairfax, the state of Virginia. Their goal is to strengthen ties between community members, preserve the cultural values and traditions of the diaspora, as well as intercultural exchange, implement the idea of building a cultural bridge between Tajikistan and the United States and thereby integrate with other communities living in America [36].

Today, talking about the economic development of the republic in conjunction with the citizens of the country living abroad, labor migrants come to the fore. The remittances that they send to their relatives in Tajikistan provide the state with the opportunity to levy taxes 
on them and provide GDP. In this case, the state acts as the beneficiary of financial flows from labor migrants, that is, the diaspora has the potential to assist in the development of Tajikistan.

\subsection{Migration from Turkmenistan}

The population of Turkmenistan today is 5.6 million people. Migration growth is minus 5,393 per year, on average minus -15 people per day [29]. The number of emigrants who moved from the country in 2017 amounted to 243,202 people. In 2013-2017, 1150 citizens of Turkmenistan received a green card, which is considered the lowest figure among the former Soviet republics [29].

The Turkmen community in the United States is very small, although labor migrants leave the country, but it is difficult to conduct a reliable analysis of migration from Turkmenistan. The main reason for external migration in Turkmenistan is unemployment, the level of which in 2017 amounted to $60 \%$, as well as issues of citizens' security. Turkmenistan faced serious social difficulties due to water shortages, environmental problems, food security issues, which forced a part of the population to external migration. There are no official data on social issues in the country, including population migration. The government keeps statistics under strict control. Since the activities of international organizations directly involved in the protection of human rights are not allowed in Turkmenistan, their reports on migration from Central Asia do not contain specific information about Turkmenistan. Turkmenistan has a state policy on regulating migration; there is a package of legislative documents related to the migration policy of Turkmenistan. According to unofficial information from the State Migration Service, about 110 thousand of the more than 150 thousand people, who left the country in January-September 2018, stated that they did not intend to return. Most tourists, who have received tourist visas do not return to the country, remain as illegal immigrants. There is information that measures are being taken to return citizens of Turkmenistan from abroad, especially labor migrants and students studying in foreign universities [37].

Men under the age of 30 in Turkmenistan are not allowed to travel abroad. In turn, the US Migration Service is taking particularly stringent measures for citizens of Turkmenistan who remain in the United States in an illegal status.

Table 5. Migration from Turkmenistan to the USA. The number of persons obtained the status of U.S.

\begin{tabular}{c|c|c|c|c|c|c}
\hline Year & $2002-2010$ & $2011-2015$ & 2016 & 2017 & 2018 & Total \\
\hline legal resident & 1695 & 1173 & 235 & 251 & 286 & 3640 \\
\hline refugee & no data & & & & & \\
\hline citizenship & 686 & 705 & 102 & 109 & 117 & 1719 \\
\hline Total & 2381 & 1878 & 337 & 360 & 403 & 5359 \\
\hline
\end{tabular}

Data based on summary data [15-17] (Calculated by us - M.G. \& Z.I.)

The Turkmen community in the United States is very small. It should be noted, that stringent measures are being taken by the US Migration Service for citizens of Turkmenistan due to security concerns.

\section{Conclusion}

It can be argued that the current scope of migration processes on the globe correlates with the priority goals of the 2030 Agenda for Sustainable Development. 
From this standpoint, the United States is regarded as one of the leading Western countries with the most attractive migration policies. Despite a slight decrease in the rate of migration in the US due to the Trump administration's restrictions, the US remains one of the stable and attractive directions of external migration for citizens of the Central Asian republics.

At the present time, there is no general methodological approach to scientific discourse, instead there are disagreements in the methods of statistical measurement of migration, in particular at the national level, which affects the quality and conflicting results. The phenomenon of modern migration in the context of globalization is developed mainly by Western science and scholars. The problem of migration from the countries of Central Asia to the western countries, including the United States remains a poorly studied topic requiring a balanced approach and practical recommendations.

In the light of globalization, the process of migration to the Western countries over the years is increasingly regarded as a "painful loss" by the Central Asian countries, not just labor resources, but the intellectual elite, the educated part of the population. As a result, this process is widely perceived as a brain drain. These educated and skilled Central Asians are settling in the developed states like the USA, Canada, Germany, France and other western countries.

A particularly disturbing trend in recent years has been characteristic of a number of Central Asian countries. The new trend of educational migration leads to the erosion of the educated generation of young people, and the formation of peculiar voids in the Central Asian societies.

Ethnic migration and narrowing of the field of "multinational" communities of Kazakhstan, Kyrgyzstan, Uzbekistan, respectively, and understanding the role of the diaspora factor in modern Central Asian states require onwards research that is more thorough and deep analyses.

The problems linked to tightening the US immigration policy and strengthening state security, specifically the so-called 'terrorist threat', cannot be considered outside the context of foreign policy objectives.

To assess migration not as a menacing and risky phenomenon, but as an integral part of global development, it is important to increase the stability of the migration process in the framework of the Sustainable Development Goals and start developing common legal regulation of the migration process and phenomenon.

\section{References}

1. United Nations High-Level Dialogue on International Migration and Development (HLD) https://www.iom.int/united-nations-high-level-dialogue-internationalmigration-and-development-hld

2. United Nations General Assembly, Transforming our world: the 2030 Agenda for Sustainable Development https://www.unfpa.org/resources/transforming-our-world2030-agenda-sustainable-development

3. Global Forum on Migration and Development (GFMD) https://www.gfmd.org/

4. D. Massey, J. Arango, G. Hugo et al., Population and Development Review, 19(3), 431466 (1993)

5. W. Zelinsky, Geographical Review, 61, 219-249 (1971)

6. M. Okolski, International Migration, 40, 125-150 (2002)

7. D. Nayyar, Cross-Border Movements of People (The United Nations University, Helsinki, 2000)

8. R. Skeldon, Migration and Development: A Global Perspective, $52-53$ (Longman, Essex, 1997) 
9. The General Assembly, Declaration of the High-level Dialogue on International Migration and Development https://www.iom.int/files/live/sites/iom/files/What-WeDo/docs/Final-Declaration-2013-En.pdf

10. The UN Refugee Agency, New York Declaration for Refugees and Migrants https://www.unhcr.org/584689257.pdf

11. International Organization for Migration, Global Compact for Safe, Orderly and Regular Migration https://www.iom.int/

12. U.S. Citizenship and Immigration Services (USCIS), Immigration and Nationality Act of 1990 https://www.uscis.gov/

13. REAL ID Act of 2005 https://www.dhs.gov/xlibrary/assets/real-id-act-text.pdf

14. UN Migration Data Portal https://migrationdataportal.org/

15. The United States Department of Homeland Security (DHS), Yearbook of Immigration Statistics 2018 https://www.dhs.gov/immigration-statistics/yearbook/2018

16. The United States Department of Homeland Security (DHS), Yearbook of Immigration Statistics 2014 https://www.dhs.gov/immigration-statistics/yearbook/2014

17. The United States Department of Homeland Security (DHS), Yearbook of Immigration Statistics 2014 https://www.dhs.gov/immigration-statistics/yearbook/2011

18. M. Gubaidullina, Eurasian Politics. Ideas, Institutions and External Relations, 133-150 (2013)

19. S. Rajan, L. Delovarova, International relations and international law journal, 2, 97-108 (2018)

20. M. Laruelle, Migration and social upheaval as the face of globalization in Central Asia (Brill, 2013)

21. A. Chekirova, Kyrgyz Communities in the United States: Beyond Myths and Stereotypes (IWPR, CABAR, 2019)

22. M. Buriev, What is the Potential of Tajik Diasporas in the Development of Tajikistan? (IWPR CABAR, 2019)

23. Zh. Idrysheva, A. Kulbayeva, B. Balaubayeva, Actual Problems of labor relations in the regional socio-humanitarian studies, 30-36 (2015)

24. S. Liebert, S. E. Condrey, and D. Goncharov, Public administration in post-communist countries: Former Soviet Union, central and Eastern Europe, and Mongolia (CRC Press, 2013)

25. C. Sadowski-Smith, New Immigrant Whiteness: Race, Neoliberalism, and Post-Soviet Migration to the United States (Nation of Nations), 230 (NYU Press, 2018)

26. F. T. Miko, G. Park, Trafficking in women and children: The U.S. and international response, 23 (Washington, DC: Congressional Research Service, 2001)

27. S. Pierce, A. Selee, Migration policy institute, 1-15 (2017)

28. Migration Policy Institute, Frequently Requested Statistics on Immigrants and Immigration in the United States https://www.migrationpolicy.org/

29. UN states-population https://www.worldometers.info/

30. Pew Research Center, Key findings about U.S. immigrants https://www.pewresearch.org/

31. The White House, Executive Order Protecting The Nation From Foreign Terrorist Entry Into The United States https://www.whitehouse.gov/

32. Harriman Institute, Central Asiandiaspora in the USA: the case of Kyrgyz Americans https://harriman.columbia.edu/

33. U.S. Department of State - Bureau of Consular Affairs, Visa Bulletin for August 2019, https://travel.state.gov/

34. G. Mendikulova, Istorisheskiye sudby kazakskoi diaspory. Proishozhdeniye i razbitie, 264 (Almaty, 1997)

35. Sputnik, Kogda i pri kakih usloviyah SShA snimut visovyi zapret dlya kyrgyzstanthev https://ru.sputnik.kg/

36. Tajik-American cultural association, TACA: https://www.facebook.com/pg/

37. General information about Turkmenistan https://www.pragueprocess.eu/ 